\title{
Šilumos sąnaudų gyvenamųjų namų šildymui palyginimo ir poreikių prognozavimo pagal šildymo dienolaipsnius taikomumo ribos
}

\section{Egidijus Juodis}

Vilniaus Gedimino

technikos universitetas,

Sauletekio al. 11, LT-10223 Vilnius

El.paštas: egidijus.juodis@vgtu.lt
Ivairaus klimato vietovių pastatų šilumos sąnaudoms palyginti ir ịvertinti naudojami šildymo dienolaipsniai (ŠDL). ŠDL skaičiuotè remiasi vietovès klimato charakteristikomis ir bazine temperatūra. Bazinè temperatūra yra lygi balansinei pastato temperatūrai, kai pastato šilumos išsiskyrimai kompensuoja šilumos nuostolius. Perèjus prie energiškai efektyvių pastatų statybos, šilumos nuostoliai mažèja, didèja šilumos pritekèjimo vaidmuo. Kyla klausimas, iki kokio šilumos sąnaudų lygio šildymo dienolaipsniai yra pakankamai patikimas ịrankis ịvairaus klimato pastatų šilumos sąnaudoms vertinti ir poreikiams prognozuoti.

Šilumos sąnaudos šildymui, tenkančios vienam šildymo dienolaipsniui, pasirinkus teisingą bazinę temperatūrą, nepriklauso nuo pasirinkto laikotarpio dienolaipsnių skaičiaus. Sugretinus Lietuvos šilumos tiekimo įmonès ịvairių miestų komercinių atsiskaitymų už sunaudotą šilumą daugiabučių namų mėnesines šilumos sąnaudas ir santykines sąnaudas, tenkančias vienam šildymo dienolaipsniui, pagrindžiama išvada, kad šildymo dienolaipsniai, nustatyti remiantis bazine temperatūra $18^{\circ} \mathrm{C}$ arba artima jai, neturi būti taikomi energiškai efektyviems pastatams. İ ši dienolaipsnių skaičių itraukiami periodai, kai energiškai efektyvių pastatų nereikia šildyti.

Rasta, kad bazine temperatūra pastatams, kuriuose šilumos sąnaudos yra $40 \mathrm{kWh} /$ $\mathrm{m}^{2}$ met., laikytini $8{ }^{\circ} \mathrm{C}$, o esant sąnaudoms $75 \mathrm{kWh} / \mathrm{m}^{2} \mathrm{met}$. $-10{ }^{\circ} \mathrm{C}$. Nèra esminių skirtumų tarp Lietuvos Respublikos ir kaimyninių šalių statybos tradicijų, gyventojų ịpročių, buitinès ịrangos, todèl galima teigti, kad šios bazinès temperatūros gali būti taikomos visose Baltijos rytinès pakrantès šalyse.

Raktažodžiai: šildymo dienolaipsniai, energiškai efektyvūs pastatai, bazinė temperatūra

\section{IVADAS}

Pastatų šildymui Europoje tenkanti sunaudojamos energijos dalis yra didžiausia iš sąnaudų, palyginti su visomis kitomis reikmėmis - apšvietimu, maisto ruošimu, vėsinimu, liftais ir kt., todèl energijos taupymas šildymui, ypač vėsaus klimato šalyse, yra itin svarbus tiek valstybės mastu, tiek gyventojams $[1,4,6]$. Ivairių vietovių pastatų ir laikotarpių šilumos sąnaudoms palyginti bei îvertinti plačiai naudojami šildymo dienolaipsniai (ŠDL). Dienolaipsnių naudojimas igalina nustatyti energinio efektyvumo pokyčius ir iqvertinti kvalifikuotos pastato energetinès vadybos rezultatus, numatyti, palyginti ir kontroliuoti kuro sąnaudas šildymo katilinèse. 
Šilumos reikalavimai gyvenamiesiems namams yra išsamiau išnagrinèti ir parengti nei visuomeninès paskirties pastatams. Net jei gyvenamieji namai yra unikalūs, jie skiriasi vienas nuo kito mažiau nei kitu paskirčių pastatai, nes turi atitikti tuos pačius norminius dokumentus, juose vyksta tie patys procesai. Esminis skirtumas tarp gyvenamųju namų - tik jų energinio efektyvumo lygis.

ŠDL skaičiuotė remiasi vietovès klimato charakteristikomis [13] ir bazine temperatūra. Bazinè temperatūra yra lygi balansinei pastato temperatūrai, kai pastato šilumos išsiskyrimai kompensuoja šilumos nuostolius, tada pastato nereikia nei šildyti, nei vessinti $[1,4]$. Tai reiškia, kad kiekvienam pastatui ar identiškų šiluminių charakteristikų pastatų grupei būdinga skirtinga bazinè temperatūra. Šilumos pritekejjimas (iš žmonių, kompiuterinès įrangos, karšto vandentiekio sistemos ir t. t.) kompensuoja dali šilumos nuostolių, todèl balansinè temperatūra yra žemesnè už pastato vidaus temperatūrą.

Perejjus prie energiškai efektyvių pastatų statybos, šilumos sąnaudos šildymui mažèja, atsiranda pastatų, kurių šilumos nuostolius kompensuoja vidiniai šilumos išsiskyrimai ir saulès spinduliuotè. Tai reiškia, kad šilumos sąnaudoms šildymui artėjant link nulio mènesinis ar metinis ŠDL skaičius tampa vis mažiau svarbus, ŠDL besiremiančios šilumos poreikio prognozés tampa neteisingos, o dienolaipsniai naudojami tik klimato charakteristikai. Šilumos poreikio palyginimui siūloma įvesti klimato atšiaurumo rodiklị (climate severity index), t. y. šilumos poreikio pasirinktoje vietovejje santykị su poreikiu kontrolinėje vietoveje. Tarkime, pastato šilumos poreikis šildymui ịvairiose vietovèse lyginamas su kontroliniu, pvz., Madride [12]. Papildžius [12] duomenis tų vietovių oro uostų ŠDL vertėmis [3], kai bazinè temperatūra $20^{\circ} \mathrm{C}$, sudaryta 1 lentelè.

Didžiausio ir mažiausio 1 lentelèje šilumos poreikio santykis (žiemos klimato atšiaurumo indeksas) skiriasi 8, kai ŠDL ${ }_{20}$ - tik 3 kartus. Tai paaiškintina tuo, kad šilu- mos išsiskyrimų, ypač dèl saulès spinduliuotès, ir pastato šilumos nuostoliu santykis Europos pietinëje dalyje yra daug didesnis nei einant $\mathfrak{i}$ šiaurę. Energiškai efektyviuose pastatuose taip pat šis santykis yra didesnis nei netaupiai naudojančiuose energiją. Suomijoje techniškai ir ekonomiškai priimtinomis pasyvių pastatų šilumos sąnaudomis laikoma $20-30 \mathrm{kWh} / \mathrm{m}^{2}$ met. [11]. Tai patvirtina abejonę, ar plačiai naudojami ŠDL ${ }_{18}$, ar kitai netaupių pastatų bazinei temperatūrai apskaičiuoti šildymo dienolaipsniai yra pakankamai patikimas įrankis energiškai efektyvių pastatų palyginimui.

Kai kurie tyrëjai energijos poreikio priklausomybèje nuo ŠDL įveda pastovią dedamąją, tai taip pat gali reikšti, kad jų panaudota bazinè temperatūra nelygi balansinei [7].

Nagrinejjant šilumos sąnaudų pastatų šildymui mažinimo galimybes vyrauja dėmesys konstrukcinèms ir eksploatacinėms priemonėms bei šių priemonių atsipirkimui, trūksta dèmesio ịvairaus klimato pastatų šilumos sąnaudu palyginimo pagrịstumui. Šilumos sąnaudos, $\mathrm{kWh} / \mathrm{m}^{2}$ met., gyvenamuosiuose namuose labai svyruoja, todèl kyla klausimas, iki kokio šilumos sąnaudu lygio šildymo dienolaipsniai yra pakankamai patikimas įrankis lyginant įvairaus klimato pastatų šilumos sąnaudas ir prognozuojant šilumos poreikius.

\section{METODIKA}

Šilumos sąnaudomis gyvenamujų pastatų šildymui šiame straipsnyje vadinamas skirtumas tarp šilumos nuostoliu per atitvaras ir nuostolių su vėdinimu oru, atmetus vidinius ir išorinius šilumos pritekẻjimus, tai ịvadinių pastato šilumos skaitiklių išmatuotas dydis, už kurị sumokama šilumos tiekejjui. Pastato energinis efektyvumas (naudingumas) čia nagrinëjamas siauriau nei ji apibrěžia ES dokumentai [6], neitraukiama elektros energijos visoms reikmèms bei šilumos karštam vandeniui ruošti.

1 lentelè. Šilumos poreikio identiškam pastatui j̨vairiu klimatu ir ŠD $\mathrm{L}_{20}$ santykio palyginimas

\begin{tabular}{|c|c|c|c|}
\hline Vietovè & $\begin{array}{c}\text { Klimato atšiaurumo } \\
\text { indeksas }\end{array}$ & ŠDL $L_{20}$ & ŠDL ${ }_{20} /$ ŠDL $L_{20 \text { Madrid. }}$ \\
\hline Glasgow (JK) & 2,59 & 4055 & 1,61 \\
\hline Newcastle (JK) & 2,59 & 4055 & 1,61 \\
\hline Dresden (Vokietija) & 3,31 & 3947 & 1,57 \\
\hline Nottingham (JK) & 2,36 & 3655 & 1,45 \\
\hline Braunschweig (Vokietija) & 2,56 & 3573 & 1,42 \\
\hline Brighton (JK) & 1,83 & 3494 & 1,39 \\
\hline Burgos (Ispanija) & 1,96 & 3311 & 1,32 \\
\hline Milan (Italija) & 1,81 & 3123 & 1,24 \\
\hline Agen (Prancūzija) & 1,44 & 2769 & 1,10 \\
\hline Madrid (Ispanija) & 1,00 & 2513 & 1,00 \\
\hline Granada (Ispanija) & 0,81 & 2375 & 0,95 \\
\hline Rome (Italija) & 0,83 & 1945 & 0,77 \\
\hline Lisbon (Portugalija) & 0,37 & 1491 & 0,59 \\
\hline Trapani (Italija) & 0,32 & 1348 & 0,54 \\
\hline
\end{tabular}


Lyginant ịvairaus klimato pastatų apvalkalo ir jų šildymo bei vẻdinimo sistemų kokybę neišvengiamai tenka šilumos sąnaudas perskaičiuoti, pasitelkus šildymo dienolaipsnius. Vertinant pastatų energini efektyvumą pagal iš išorès patiektos (perkamos) energijos kiekị ì pastato šilumini balansą įtraukiami ne tik šilumos nuostoliai per atitvaras, su šalinamu védinimo oru bei šilumos išsiskyrimai, bet ir ịvairiais būdais statybos objekte generuojama energija, kurios šaltiniai yra saulès spinduliuotè ir t. t. Tokiais būdais galima pasiekti nulinị perkamos šilumos poreikį, pasyvaus pastato šilumos sąnaudų rodiklį $15 \mathrm{kWh} /$ $\mathrm{m}^{2}$ met., tačiau šis rodiklis yra tik perkamos šilumos kiekis, išvestas vidurio Europos klimatui, ir tik iš dalies apibūdina pačio pastato energinị ir ekonominị efektyvumą, nes bet kuris pastatas, įrengus gausią papildomą ịrangą, gali pasiekti pasyvaus pastato lygi.

Šioje analizėje buvo priimtos tokios prielaidos:

- visi nagrinejjamieji pastatai yra gyvenamieji namai, jų šiluminis inertiškumas yra to pačio lygio ir neturi įtakos balansinei temperatūrai;

- šilumos sąnaudų matavimų prietaisų rodmenys yra fiksuojami paskutinę mẻnesio dieną;

- šildymas šildymo laikotarpiu yra nepertraukiamas;

- energiškai neefektyviuose ir taupiai naudojančiuose šilumą daugiabučiuose namuose vyksta tie patys buitiniai procesai, todèl laikoma, kad absoliutinès šilumos pritekejjimo vertès yra tokios pačios;

- laikoma, kad būstų vidutinè temperatūra $20^{\circ} \mathrm{C}$;

- visuose gyvenamuosiuose namuose nèra oro tiekimo su šilumos grąža sistemų, namai vẻdinami natūraliai ir oro ištraukiamaisiais ventiliatoriais iš virtuvės gaubto arba sanitarinių mazgų.

Idealiu atveju, kai nèra šilumos išsiskyrimų, mėnesio ar kito laikotarpio šilumos sąnaudos šildymui yra lygios šilumos nuostoliams ir pastatui šildyti aprašomos lygtimi:

$$
Q=H n_{\check{S} D L}, \mathrm{kWh} ;
$$

čia: $H$ - pastato savitieji šilumos nuostoliai, $\mathrm{kWh} / \mathrm{K}$; $n_{\tilde{S} D L}$ - pasirinkto laikotarpio šildymo dienolaipsnių skaičius, ${ }^{\circ} \mathrm{C}$ para.

Gyvenamuosiuose namuose visada yra didesni ar mažesni šilumos pritekèjimai iš žmonių, karšto vandentiekio sistemos, kompiuterinès ir kitos ịrangos, saulès spinduliuotès, todèl šilumos sąnaudos šildymui yra mažesnès nei šilumos nuostoliai. Pasirinkto laikotarpio šilumos poreikis:

$$
Q=H n_{\check{S} D L}-Q_{p}
$$

čia: $Q_{p}$ - šilumos pritekèjimai, $\mathrm{kWh}$.

Šioje priklausomybëje esantis $n_{\check{S} D L}$ priklauso nuo pasirinktos bazines temperatūros, jei matavimai vykdomi kas valandą:

$$
n_{\text {SूLL }}=\frac{\sum\left[\left(t_{b}-t_{e x}\right) n\right]}{24},{ }^{\circ} \mathrm{Cpara} ;
$$

čia: $t_{e x}$ - lauko oro temperatūra, ${ }^{\circ} \mathrm{C} ; n$ - atitinkamos lauko oro temperatūros trukmè, $h ; t_{b}$ - bazinè temperatūra, ${ }^{\circ} \mathrm{C}$.

Kylant pastatų energiniam efektyvumui mažèja jų šilumos nuostoliai, todèl didèja vidinių šilumos išsiskyrimu vaidmuo, žemëja balansinè temperatūra ir atitinkamai skaičiuojamoji bazinè temperatūra. Ivairiose valstybėse skiriasi gyventojų ipročiai, statybos tradicijos, todèl ŠDL apskaičiuojami pagal skirtingas bazines temperatūras. Vidiniai šilumos išsiskyrimai, tradiciniuose prastai izoliuotuose namuose, pakelia temperatūrą apie $3{ }^{\circ} \mathrm{C}[8]$, pagal nutylejimą laikant, kad gyvenamuosiuose namuose oro temperatūra turètų būti komfortiška $20-21{ }^{\circ} \mathrm{C}$, bazinè temperatūra Europos Sąjungoje dažniausiai priimama $18{ }^{\circ} \mathrm{C}$ (JAV $18,3{ }^{\circ} \mathrm{C}$, Jungtinèje Karalysteje tradiciškai vèsiau, todèl $15,5{ }^{\circ} \mathrm{C}$ [4]). Tokiu būdu automatiškai ịvertinami šilumos išsiskyrimai ir šilumos sąnaudos šildymui tampa tiesiog proporcingos ŠDL.

Šilumos nuostolių ir išsiskyrimų verčių apskaičiavimo metodika ir kompiuterinès programos yra pakankamai išsamiai parengtos, todèl iškeltą uždavinị galima spręsti analitiškai. Analitiškai sprendžiant kai kuriuos pradinius duomenis tenka ịstatyti skaičiuotojo nuožiūra, pvz., mechaninès oro kaitos ir infiltracijos, vidiniu šilumos išsiskyrimu duomenis. Savo ruožtu, šie duomenys priklauso nuo pastato būklès, gyventoju îpročių ir t. t., todèl šioje analizejje pasirinkta remtis realiais komercinių atsiskaitymų už sunaudotą šilumą rezultatais. Skaitmeninè bazinès temperatūros vertè ir pagal ją apskaičiuotų šildymo dienolaipsnių pritaikomumas nustatytas naudojant regresinę analizę.

\section{Pastatų pasirinkimas}

Pastatai parinkti pagal Lietuvos šilumos tiekẻjų asociacijos (LŠTA) skelbiamus oficialius šilumos sąnaudų duomenis. Visų LŠTA priklausančių šilumos tiekimo i̇monių daugiabučių gyvenamųjų namų mėnesinès šilumos sąnaudos pateikiamos LŠTA „Šilumos suvartojimo analizèje“ pagal šilumos tiekejjų nusistatytas pastatų energinio efektyvumo grupes [9], nes šilumos sąnaudų duomenų bazè pagal pastatų energinio sertifikavimo klases dar nesudaryta. $\mathrm{Pa}-$ sinaudota 2010 m. gruodžio - $2012 \mathrm{~m}$. balandžio mèn. šilumos sąnaudų rodikliais pagal šią daugiabučių gyvenamujų namų klasifikaciją (2 lentelè).

Iš viso kiekvienoje grupeje yra per 100 namų duomenys, tačiau grupių sudètis keičiasi kiekvieną mènesị pagal tai, kokie namai tą mènesị sunaudojo mažiausiai ar daugiausiai šilumos. Atmetus nepasikartojančius objektus, nepakankamai aiškius duomenis, pasirinkti Vilniaus, Kauno ir Panevèžio gyvenamieji namai, kiekvienoje grupeje liko po 20-25 daugiabučius namus, o kiekvieno miesto 4-8 namai. Tais 
2 lentelè. LŠTA daugiabučių gyvenamujų namų klasifikacija [9]

\begin{tabular}{|c|c|c|c|}
\hline \multirow[b]{2}{*}{ Pastatų grupės apibūdinimas } & \multicolumn{2}{|c|}{ Šilumos šildymo sąnaudos } & \multirow[b]{2}{*}{ Pastatų dalis \% } \\
\hline & kWh/m²mèn. & $\begin{array}{l}60 \mathrm{~m}^{2} \text { ploto butui } \\
\mathrm{kWh} / \mathrm{met} \text {. }\end{array}$ & \\
\hline $\begin{array}{l}\text { I. Daugiabučiai, suvartojantys mažiausiai šilumos } \\
\text { (naujos statybos, kokybiški namai) }\end{array}$ & 8 & 480 & 4,6 \\
\hline $\begin{array}{l}\text { II. Daugiabučiai, suvartojantys mažai arba vidutiniškai šilumos } \\
\text { (naujos statybos ir kiti kažkiek taupantys šilumą namai) }\end{array}$ & 15 & 900 & 17,3 \\
\hline $\begin{array}{l}\text { III. Daugiabučiai, suvartojantys daug šilumos } \\
\text { (senos statybos nerenovuoti namai) }\end{array}$ & 25 & 1500 & 55,7 \\
\hline $\begin{array}{l}\text { IV. Daugiabučiai, suvartojantys labai daug šilumos } \\
\text { (senos statybos, labai prastos šiluminès izoliacijos namai) }\end{array}$ & 35 & 2100 & 22,4 \\
\hline
\end{tabular}

atvejais, kai kas ménesị kurio nors miesto nuolat pasikartojančių objektų buvo mažiau nei keturi, parenkant objektus buvo atmetami didžiausių ir mažiausių šilumos sąnaudų namai, tačiau bet kuriuo atveju kiekvieno miesto analizuojamų pastatų šildomasis plotas visais mènesiais skiriasi ne daugiau $5 \%$. Pastatų, kurie atitiktų pasyvių pastatų šilumos sąnaudų kriterijų $15 \mathrm{kWh} / \mathrm{m}^{2}$ met., centralizuoto šilumos tiekimo įmonių duomenų bazèse nèra.

Analizei pasirinktos 1, 2 ir 4 grupès (žr. 2 lentelę), nes jų šilumos sąnaudos labai skiriasi, santykis artimas $1: 2: 4$. Realios šilumos mėnesinės vidutinès šilumos sąnaudos analizuojamuoju laikotarpiu buvo artimos išvardintoms 2 lentelèje. Metinių sąnaudų pasiskirstymas pateiktas 3 lentelèje.
Standartinių metų šildymo dienolaipsnių skaičius Kaune $n_{\check{S} D L 18}=3507$, Vilniuje (užmiestyje) $n_{\check{S} D L 18}=3728$ [6]. Perskaičiavus pagal standartinius metus, šilumos 20112012 žiemos sąnaudos būtų didesnès 8-10\%.

\section{REZULTATAI}

Perskaičiavus visų mėnesių šilumos sąnaudas standartiniam 30,5 parų mėnesiui, sudaryti ménesinių šilumos sąnaudų 1, 2 ir 3 pav. Ketvirtosios labai daug šilumos suvartojančių daugiabučių grupés šilumos sąnaudos, kaip ir privalo būti, yra tiesiogiai proporcingos ŠDL ${ }_{18}$ pokyčiui (1 pav.). Priimant šilumos išsiskyrimų iš vidinių šaltinių vertę $5 \mathrm{~W} / \mathrm{m}^{2}$ šildymo sezono metu jie sudarytų $Q_{p} \approx 24 \mathrm{kWh} / \mathrm{m}^{2}$ [10]. Tada

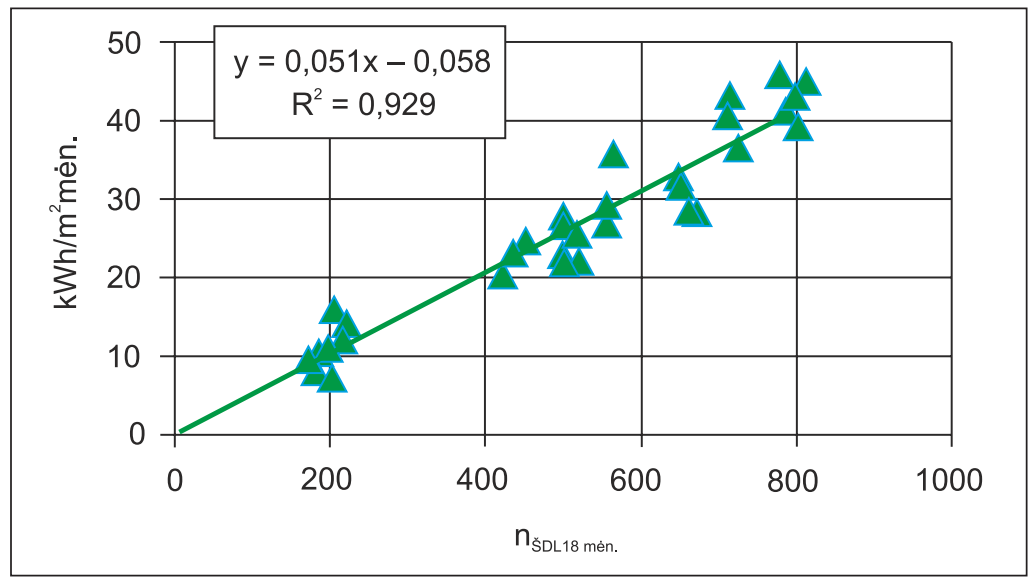

1 pav. Ketvirtosios efektyvumo grupès daugiabučių mènesio šilumos sąnaudos

3 Ientelè. Pirmosios, antrosios ir ketvirtosios pastatų grupių 2011-2012 metų šildymo sezono šilumos sąnaudos

\begin{tabular}{|c|c|c|c|c|c|c|c|}
\hline \multirow{3}{*}{ Miestas } & \multirow{3}{*}{$\mathrm{ŠDL}_{18}$} & \multicolumn{6}{|c|}{ Pastatų grupė } \\
\hline & & \multicolumn{2}{|c|}{1} & \multicolumn{2}{|c|}{2} & \multicolumn{2}{|c|}{4} \\
\hline & & $\mathrm{kWh} / \mathrm{m}^{2}$ & $W h / m^{2} S^{\prime} L_{18}$ & $\mathrm{kWh} / \mathrm{m}^{2}$ & $W h / m^{2} \mathrm{ŠDL}_{18}$ & $\mathrm{kWh} / \mathrm{m}^{2}$ & $W h / m^{2} S^{\prime} L_{18}$ \\
\hline Vilnius & $3378^{*}$ & 36,9 & 66,4 & 77,2 & 150,9 & 168,2 & 357,7 \\
\hline Kaunas & 3250 & 42,6 & 83,4 & 69,6 & 144,2 & 172,2 & 369,6 \\
\hline Panevėžys & 3240 & 39,1 & 74,4 & 62,4 & 126,3 & 155,1 & 336,3 \\
\hline
\end{tabular}

* ŠLD su indeksu 18 reiškia, kad dienolaipsniai apskaičiuoti bazinei temperatūrai $t_{b}=18^{\circ} \mathrm{C}$. 

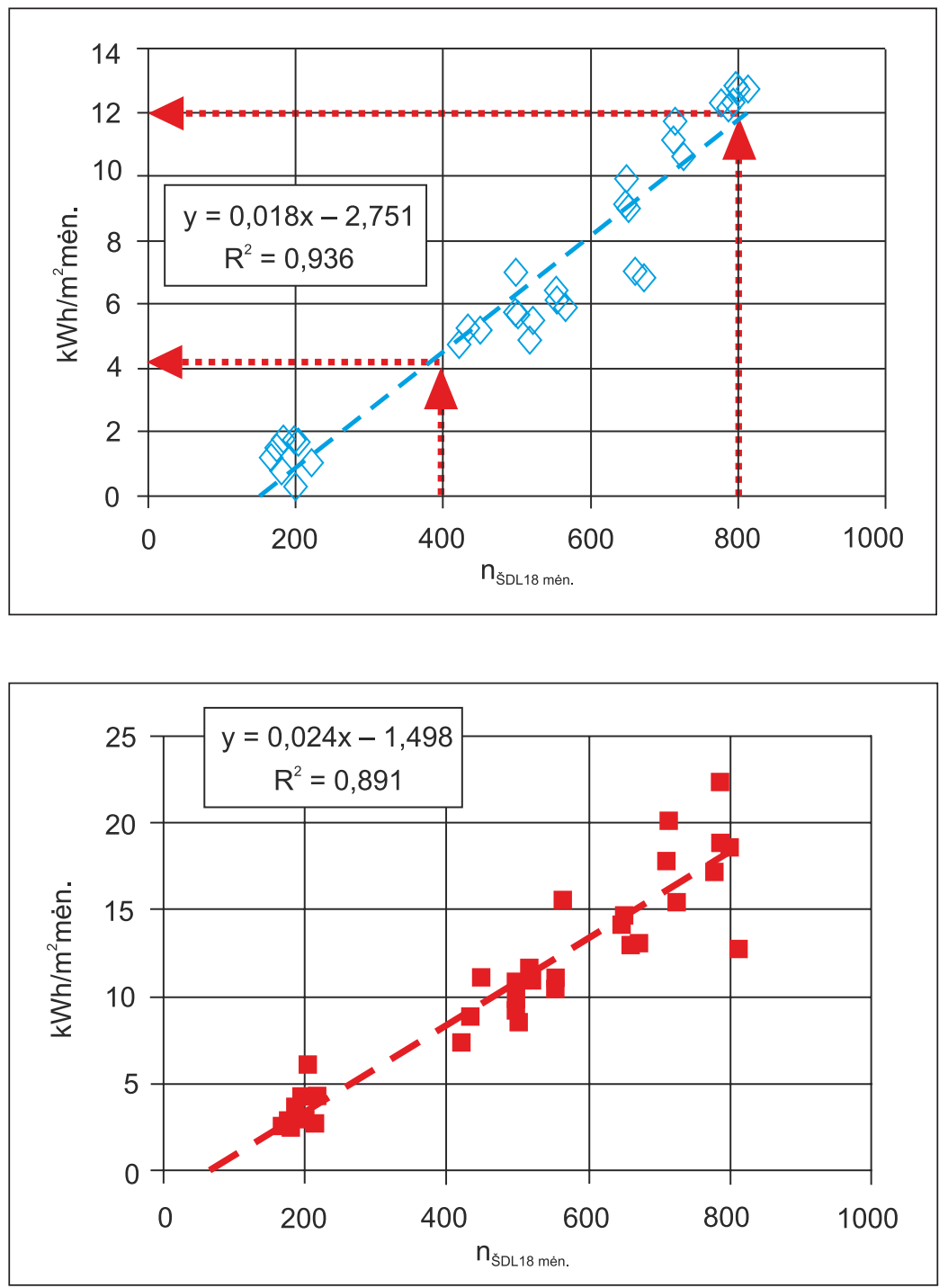

2 pav. Pirmosios efektyvumo grupés daugiabučių mènesinès šilumos sąnaudos

3 pav. Antrosios efektyvumo grupés daugiabučių mènesinès šilumos sąnaudos ketvirtosios grupès namų šilumos nuostoliai (žr. 2 lentelę) $H n_{\check{S} D L} \approx 194 \mathrm{kWh} / \mathrm{m}^{2}$, juose šilumos išsiskyrimų ir nuostolių santykis $Q_{p} / H n_{\check{S} D L}=0,12$.

Grafikai rodo (2 ir 3 pav.), kad pirmosios (mažiausiai naudojančių) ir antrosios (mažai naudojančių) grupių daugiabučių namų nereikia šildyti, kol mėnesinis ŠDL ${ }_{18}$ skaičius neviršija: pirmajai grupei $-152{ }^{\circ} \mathrm{C}$ para; antrajai $-61{ }^{\circ} \mathrm{C}$ para. 2 ir 3 pav. matyti, kad šilumos sąnaudos nèra tiesiogiai proporcingos ŠDL ${ }_{18}$ pokyčiui, nes nustatant $\mathrm{n}_{\check{S} D L 18}$ iskaičiuojami laikotarpiai, kai mažai energijos naudojančių pastatų šildyti nereikia. Konkrečiu atveju (2 pav., ménesiniai ŠDL ${ }_{18}$ pažymèti rodyklemis) pirmosios grupès daugiabučiams proporcingai $\breve{S L L}_{18}$ perskaičiavus šilumos sąnaudas, paklaida siekia $30 \%$.

Naudojantis kitų šalių energiškai efektyvių pastatų statybos patirtimi, būtina jų šilumos sąnaudas perskaičiuoti vietinėmis sąlygomis. Dažniausiai tai atliekama palyginus metinius $\check{S} D L_{18}$ skaičius. Lygiai taip pat, kaip ir perskaičiuojant mėnesines sąnaudas, šiltesnio klimato šalyse šilumos pritekejjimai kompensuoja didesnę metinių šilumos nuostolių dalį, todèl perskaičiavimas vėsesniam klimatui proporcingai metiniam ŠDL ${ }_{18}$ duoda mažesnị rezultatą. Tai reiškia, kad pagal, tarkime, Pietų Vokietijos pavyzdi pastatyto identiško daugiabučio Lietuvoje šilumos sąnaudos bus didesnès nei laukta pagal vietovių ŠDL ${ }_{18}$ santykį.

Energiškai efektyvių pastatų vertinimas naudojant $\check{S} \mathrm{DL}_{18}$ iškreipia ir kitus šilumos sąnaudų rodiklius. Bazinę temperatūrą galima rasti remiantis tuo, kad šilumos sąnaudos šildymui, tenkančios vienam šildymo dienolaipsniui, nepriklauso nuo pasirinkto laikotarpio dienolaipsnių skaičiaus. Tai imanoma dviem atvejais - arba nèra šilumos pritekèjimo, arba dienolaipsnių nustatymui pasirinkta teisinga bazinè temperatūra. Šilumos pritekèjimas naudojamuose pastatuose visada egzistuoja, todèl kyla klausimas, iki kokio dydžio metinių šilumos sąnaudų $\mathrm{kWh} / \mathrm{m}^{2}$ met. dar galima laikyti, kad šilumos sąnaudos, tenkančios vienam $18{ }^{\circ} \mathrm{C}$ pagrindu apskaičiuotam šildymo dienolaipsniui, yra pastovios. Tam, kad rastume atsakymą i ši klausimą, pateikiami 1, 2 ir 4 pastatų grupių duomenys (4, 5 ir 6 pav.) 
Regresinė analizè rodo, kad ketvirtosios grupès labai daug šilumos suvartojantiems daugiabučiams determinacijos koeficientas $\mathrm{R}^{2}=0,0105$. Galima laikyti, kad šilumos sąnaudos $\mathrm{Wh} / \mathrm{m}^{2}$ mèn. ŠDL nepriklauso nuo laikotarpio dienolaipsnių skaičiaus (4 pav.).

Antrosios grupès daugiabučių santykinès šilumos sąnaudų determinacijos koeficientas $\mathrm{R}^{2}=0,5048$, pirmosios grupès $\mathrm{R}^{2}=0,7786$ (5 ir 6 pav.). Fiziškai tai reikštų, kad santykinès šilumos sąnaudos tikrai koreliuoja su mėnesio šildymo dienolaipsnių $\check{S} L_{18}$ skaičiumi. Tai reiškia, kad pasirinkta neteisinga bazinè temperatūra. Sugretinus daugiabučių namų mėnesinių šilumos sąnauduc $\mathrm{kWh} / \mathrm{m}^{2}$ mèn. ir santykinių sąnau$\mathrm{duc} \mathrm{Wh} / \mathrm{m}^{2} \mathrm{mej}$. ŠDL priklausomumą nuo $\check{S} \mathrm{LL}_{18}$, galima daryti išvadą, kad šildymo dienolaipsniai, apskaičiuoti remiantis bazine temperatūra $18^{\circ} \mathrm{C}$, neturi būti taikomi energiškai efektyviems pastatams.

Mažai šilumos suvartojančiuose daugiabučiuose namuose bazinè temperatūra yra gerokai žemesnè už $18{ }^{\circ} \mathrm{C}$ ir dienolaipsnių skaičiaus nustatymas pagal ją iškreipia šilumos poreikio prognozę.

Nagrinejjamų daugiabučių grupių bazinès temperatūros nustatytos 7, 8 ir 9 pav.

Esant teisingai parinktai bazinei temperatūrai šilumos sąnaudos yra tiesiogiai proporcingos ŠDL skaičiui. Suvartojančiuose labai daug šilumos, ketvirtosios grupès daugiabučiuose, apibendrintos sąnaudos (apskaičiavus ŠDL ịvairioms bazinėms temperatūroms) tiksliausiai sutampa su koordinačių sistemos pradžia, kai $t_{b}=18{ }^{\circ} \mathrm{C}$ (5 pav.). Išvada: labai didelių šilumos nuostolių ketvirtosios grupès gyvenamųjų namų šilumos sąnaudų vertinimas ir palyginimas proporcingai pasirinkto laikotarpio ŠDL skaičiui, kai $t_{b}=18{ }^{\circ} \mathrm{C}$, yra pagrįstas ir priimtinas.

Mažai ar vidutiniškai šilumos naudojančių antrosios grupès daugiabučiuose šilumos sąnaudų palyginimui bazinè temperatūra turètų būti $10^{\circ} \mathrm{C}$ (7 pav.).

Nenurodant konkrečių šilumos sąnaudų rodiklių Jungtinèje Karalystèje gerai izoliuotiems pastatams su intensyviais šilumos išsiskyrimais taip pat rekomenduojama $t_{b}=10^{\circ} \mathrm{C}[4]$, skaičiuoti îvairioms bazinėms temperatūroms dienolaipsnius taip

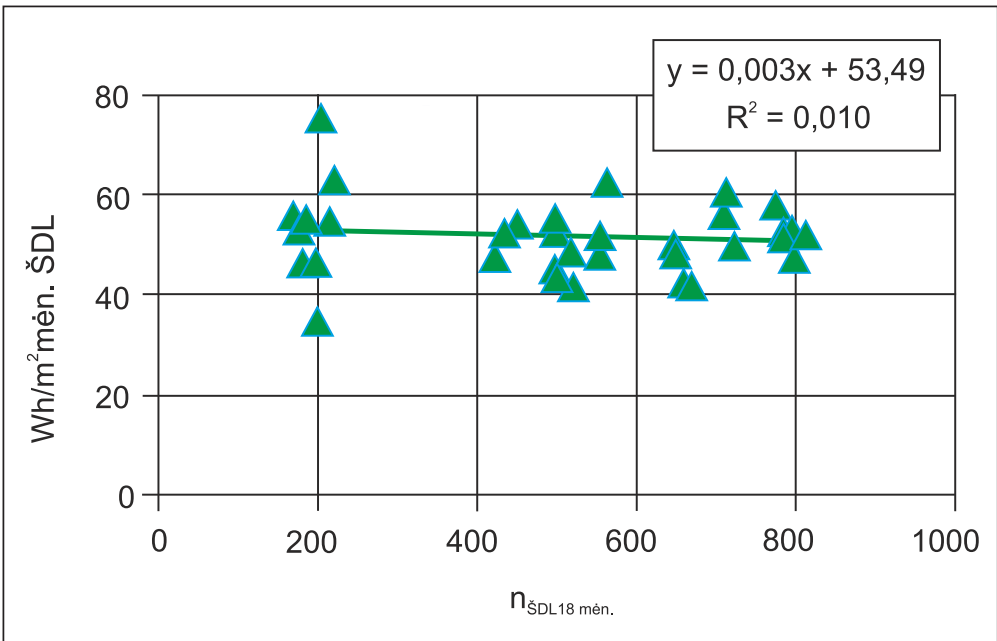

4 pav. Ketvirtosios efektyvumo grupès daugiabučiu santykinès šilumos sąnaudos, tenkančios vienam šildymo dienolaipsniui

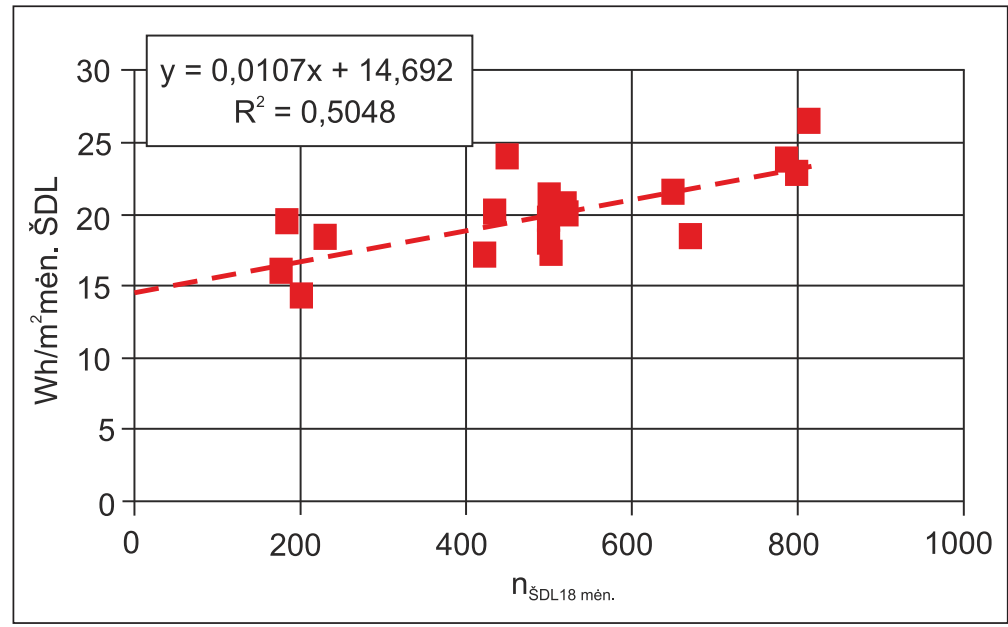

5 pav. Antrosios efektyvumo grupès daugiabučių santykinės šilumos sąnaudos, tenkančios vienam šildymo dienolaipsniui

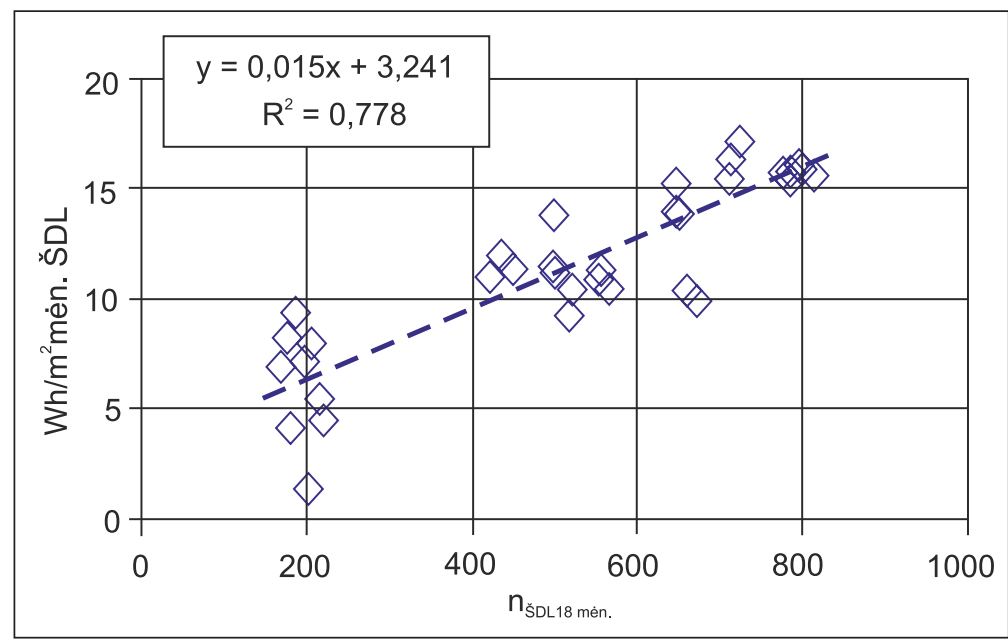

6 pav. Pirmosios efektyvumo grupès daugiabučių santykinès šilumos sąnaudos, tenkančios vienam šildymo dienolaipsniui 


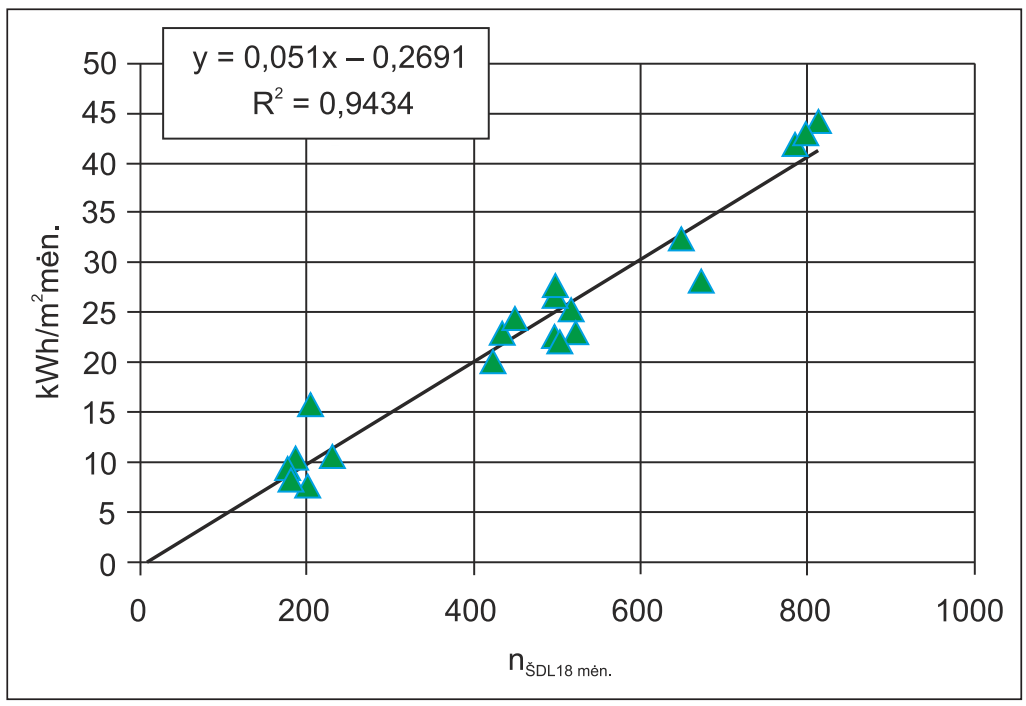

7 pav. Ketvirtosios efektyvumo grupės daugiabučių bazinè temperatūra

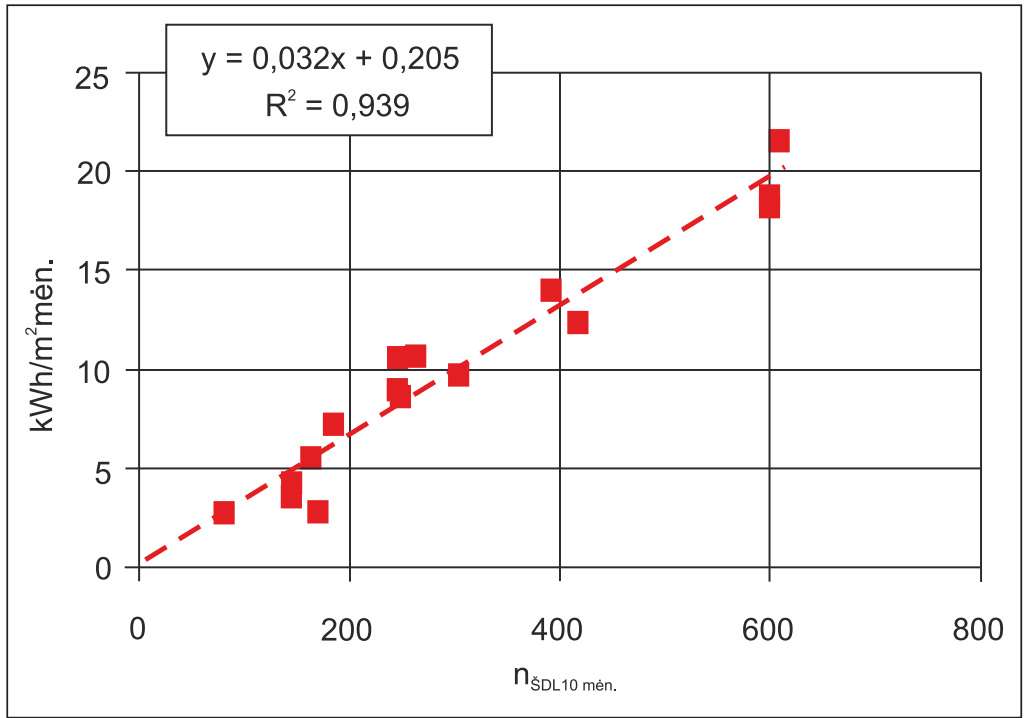

8 pav. Antrosios efektyvumo grupès daugiabučių bazinè temperatūra

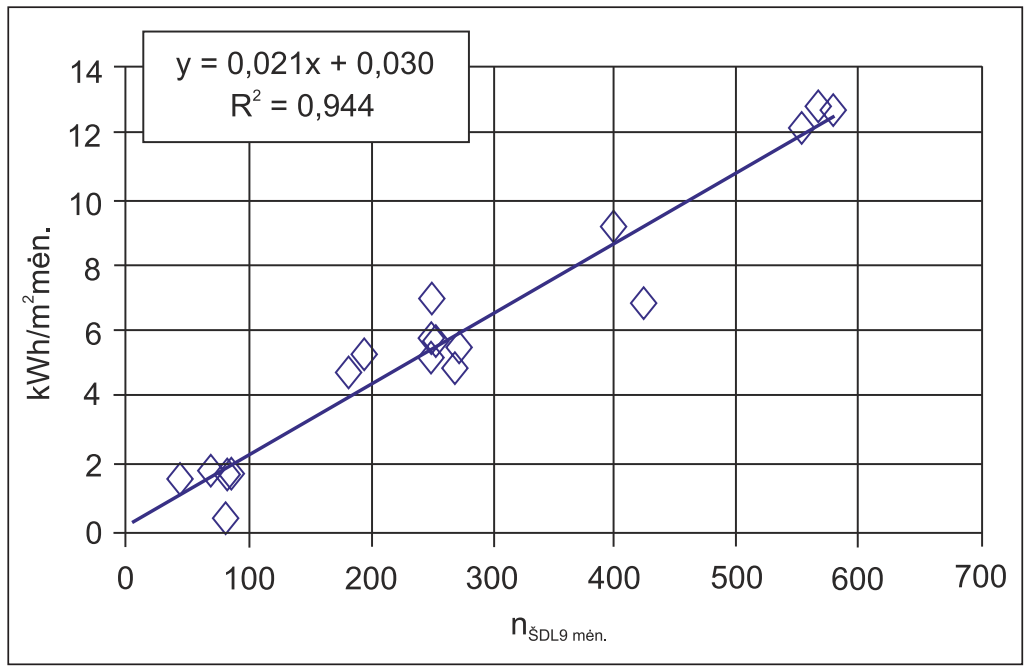

9 pav. Pirmosios efektyvumo grupès daugiabučių bazinè temperatūra pat siūloma Lenkijoje [5], JAV vietovėms nenurodant ŠDL panaudojimo srities apskaičiuota bazinėms temperatūroms nuo 65 iki $40{ }^{\circ} \mathrm{F}\left(18,3-4,4^{\circ} \mathrm{C}\right)[2]$.

Pastatų grupés apima gyvenamuosius namus pagal šilumos sąnaudas tam tikrame šilumos sąnaudų intervale, todèl grafikuose apibrežiama vidutinè namų grupès bazinè temperatūra. Iš viso mažiausiai šilumos naudojančiuose pirmosios grupès namuose bazinè temperatūra yra artima $9{ }^{\circ} \mathrm{C}(9$ pav.), o iš jų energiškai efektyviausių namų artima $6{ }^{\circ} \mathrm{C}$, todèl siūlytina pirmajai efektyvumo grupei bazine temperatūra laikyti $8^{\circ} \mathrm{C}$.

Lauktinas šilumos mėnesinių sąnaudų neapibrèžtumas priklauso nuo pastato šiluminio efektyvumo, jis didesnis mažesnių sąnaudų pastatams (žr. žemiau). Galima laikyti, kad daugiabučių, kurių metinès šilumos sąnaudos viršija $33 \mathrm{kWh} / \mathrm{m}^{2}$ met., bazinè temperatūra tiesiškai priklauso nuo metinių šilumos sąnaudų (10 pav.).

\section{REZULTATŲ PATIKIMUMAS}

Energijos sąnaudų vertinimas, kaip šildymo dienolaipsnių funkcijos neapibrèžtumas, priklauso nuo daugelio veiksnių; matavimų, aplinkos ir patalpų parametrų kitimo; pastato šiluminių charakteristikų, bazinès temperatūros ir t. t. neapibrežtumų. Visų šiu veiksnių ịtaka didẻja mažèjant bazinès ir lauko oro temperatūros skirtumui. A. R. Day ir T. G. Karayiannis atliko išsamią ménesio ir šildymo sezono dienolaipsnių skaičiaus ittakos, apskaičiuotos energijos poreikio neapibrèžtumui, analizę $95 \%$ pasikliautinumo ribose [4]. Mènesio ŠDL skaičiaus neapibrèžtumas:

$$
\varepsilon_{95 \%}=130 n_{\text {men. }}^{-1,3} \cdot 100 \%
$$

čia: $\varepsilon_{95 \%}$ - neapibréžtumas $95 \%$ pasikliautinumo ribose; $n_{\text {men..̌̉ }}-$ ménesio ŠDL skaičius; $\sum n_{\text {sežsL }}-$ šildymo sezono ŠDL suma.

Šilumos poreikio skaičiuotès pagal mènesini ŠDL skaičiu neapibrěžtumas pavaizduotas 11 pav. Daugelị ménesių šalyse aplink Baltijos jūrą mėnesinis $n_{\text {ŠDL18 }}>250$, todèl mėnesinio poreikio neapibrěžtumas 


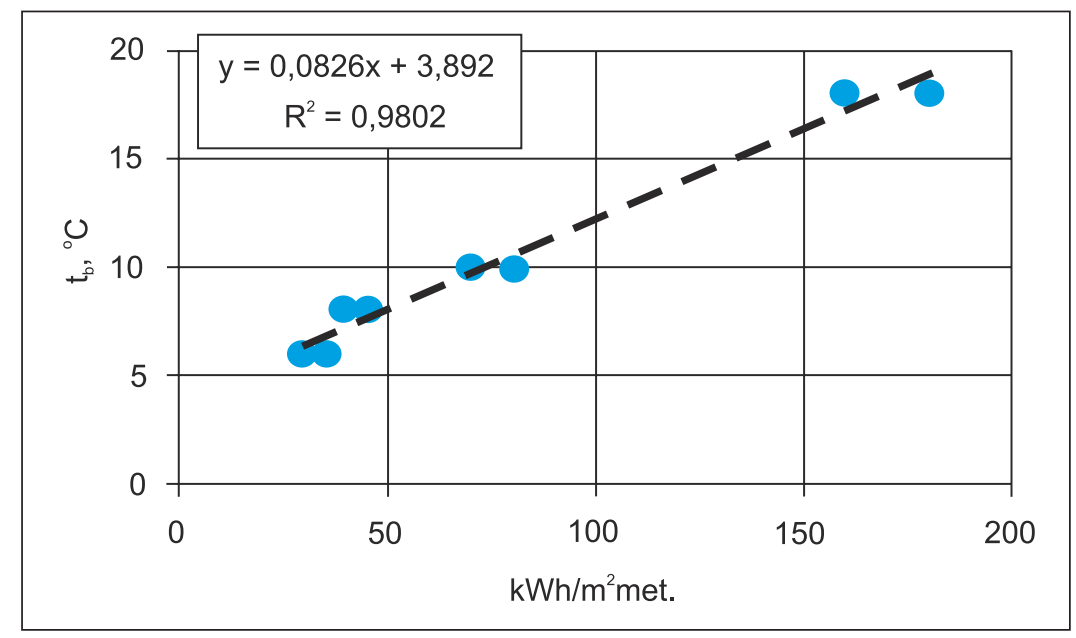

10 pav. Bazinè temperatūra įvairaus energinio efektyvumo daugiabučiuose

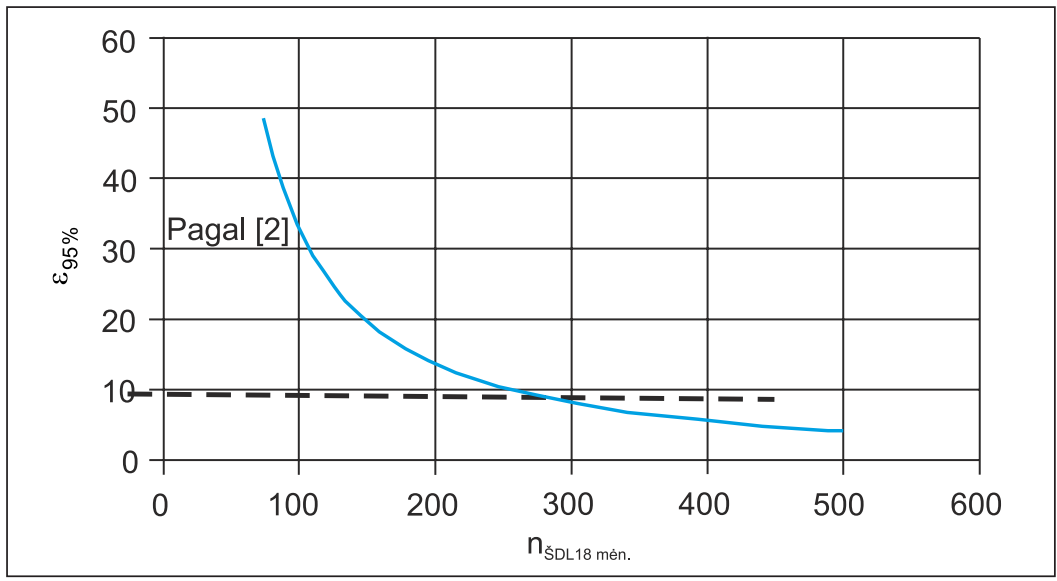

11 pav. Mènesinio energijos sąnaudų nustatymo neapibrežtumas [4]

gali viršyti 10 \% tik šildymo sezono pradžioje arba pabaigoje, kai šilumos poreikis nedidelis.

Pasirinktų miestų mėnesinis dienolaipsnių skaičius ŠDL ${ }_{18}$ kinta tarp 169 ir 812, o metinis viršija 3000 . Ivertinus šildymo periodo ịvairių mėnesių energijos poreikių indèlị ị metines sąnaudas, galima teigti, kad naudojantis ŠDL ${ }_{18}$ šilumos poreikių rodiklių metinis neapibrèžtumas neviršija $6 \%$. Analizuotame šilumos sąnaudų intervale esant žemesnei bazinei temperatūrai dèl mažesnio temperatūrų skirtumo metinis neapibrèžtumas lauktinas iki $9 \%$.

\section{REZULTATU APTARIMAS}

Taikant dienolaipsnių metodą pastato šildymui ir védinimui šilumos poreikio nustatymui priimama supaprastinimų: remiamasi vidutinėmis patalpų ir lauko oro temperatūromis, priimamos tam tikros vidinių šilumos išsiskyrimų ir infiltracinès oro kaitos vertès, todèl naudojant ši metodą rastieji rezultatai yra apytikriai. Metodo trūkumus nusveria aiški fizinė prasmè, taikymo paprastumas, pradiniai duomenys randami matavimais arba pastato projekto dokumentacijoje. Plintant energiškai efektyviems pastatams vis svarbesni tampa šilumos pritekejjimai, auga jų įtaka metinėms šilumos sąnaudoms. Šilumos pritekèjimo ịtaka didesnè šiltesnio klimato šalyse, nes jose mažesni šilumos nuostoliai. Perimant energiškai efektyvių pastatų statybos patirtị privaloma turèti patikimą ìvairaus klimato pastatų energijos sąnaudų palyginimo ịranki. I dienolaipsnių skaičių, apskaičiuotą pagal šilumos netaupančių pastatų patirtị, ịtraukiami periodai, kai energiškai efektyvių pastatų nereikia šildyti. Taigi, pastatų palyginimui ir vertinimui naudojant šildymo dienolaipsnių metodą, dienolaipsniai privalo būti apskaičiuojami pagal bazinę temperatūrą, atitinkančią pasirinktos pastatų grupès šiluminị efektyvumą.

Apdorojus šilumos tinklų įmonių matavimų duomenis, nustatytos rekomenduojamos bazinès temperatūros ịvairaus energinio efektyvumo daugiabučiams namams. Nèra esminių skirtumų tarp Lietuvos Respublikos ir kaimyninių šalių statybos tradicijų, gyventojų ịpročių, buitinès įrangos, todèl galima teigti, kad šios bazinès temperatūros gali būti taikomos visose Baltijos rytinès pakrantès šalyse. 


\section{IŠVADOS}

1. Energiškai efektyvių pastatų šilumos sąnaudų prognozavimas ir lyginimas proporcingai atitinkamo laikotarpio šildymo dienolaipsnių skaičiui, kai bazine temperatūra laikoma $18{ }^{\circ} \mathrm{C}$, yra tik kokybinis, netaikytinas inžineriniuose ir ekonominiuose skaičiavimuose.

2. Nustatyta ịvairaus šiluminio efektyvumo daugiabučiu gyvenamųjų namų balansinè temperatūra ir priklausomybẻ tarp metinio daugiabučių namų šilumos sąnaudų šildymui ir bazinès temperatūros. Bazine temperatūra pastatams, kuriuose šilumos sąnaudos šildymui ir védinimui yra $40 \mathrm{kWh} / \mathrm{m}^{2}$ met., laikytini $+8^{\circ} \mathrm{C}$, esant sąnaudoms $75 \mathrm{kWh} /$ $\mathrm{m}^{2}$ met. $-+10^{\circ} \mathrm{C}$, o energiškai neefektyviuose pastatuose, kurių šilumos sąnaudos didesnès kaip $150 \mathrm{kWh} / \mathrm{m}^{2}$ met., $+18^{\circ} \mathrm{C}$.

Gauta 20121019

Priimta 20130207

\section{Literatūra}

1. ANSI/ASHRAE/IESNA Standard 90.1-2004. Energy Standard for Buildings Except Low-Rise Residential Buildings.

2. ASHRAE Handbook: Fundamentals. American Society of Heating, Refrigerating, and Air-Conditioning Engineers, Inc., 2005. 1000 p.

3. BIZEE. Degree Days. Weather Data for Energy Professionals. Prieiga per internetą: http://www.degreedays. net/\#generate

4. CIBSE. Degree-Days: Theory and Application, TM41: 2006. Prieiga per internetą: https://www.u-cursos. cl/ingenieria/2008/1/ME550/1/material_docente/ bajar?id_material=165384

5. Dopke J. Zależności między liczbami stopniodni grzania na przykładzie Częstochowy, 2011. Prieiga per internetą: http://www.cire.pl/pokaz-pdf-\%252Fpliki\% 252F2\%252FDopke323_zaleznosc_czestochowa.pdf

6. Europos Parlamento ir Tarybos Direktyva 2010/31/ES $2010 \mathrm{~m}$. gegužès 19 d. dèl pastatu energinio naudingumo. Prieiga per internetą: http://eur-lex.europa.eu/LexUriServ/LexUriServ.do?uri=OJ:L:2010:153:0013:0035:LT: PDF

7. Kveselis V. Energijos vartojimo efektyvumo didinimo stebèsenos sukūrimas. LEI. 2008. Prieiga per internetą: http://www.ena.lt/doc_atsi/EVED_stebesena.pdf

8. Laustsen J. Energy Efficiency Requirements in Building Codes. Energy Efficiency Policies for New Buildings. International Energy Agency, 2008. Prieiga per internetą: http://www.iea.org/publications/freepublications/publication/Building_Codes-1.pdf
9. Šilumos suvartojimo analizè. LŠTA. Prieiga per internetą: http://www.lsta.lt/lt/pages/apie-silumos-uki/silumos-suvartojimo-analize

10. Nielsen L. N. Experiences from built houses and detailed building simulations calls for a careful and integrated approach when designing heating and cooling systems for nearly zero energy buildings. REHVA European HVAC Journal. 2011.

11. Nieminen J., Holopainen R., Lylykangas K. Concepts and market acceptance of a cold climate Passive House. Prieiga per internetą: www.eukn.org/dsresource? objectid $=209494$

12. The Passivhaus Standard in European warm climates: design guidelines for comfortable low energy homes. Part 1. A review of comfortable low energy homes. Prieiga per internetą:http://www.passive-on.org/CD/1.\%20Technical\%20 Guidelines/Part\%201/Part\%201\%20-\%20English.pdf

13. Statybine klimatologija RSN 156-94. Oficialusis leidinys. Vilnius, 1995. 135 p.

Egidijus Juodis

\section{THE BOUNDARIES OF HEATING DEGREE-DAYS APPLICATION TO COMPARE CONSUMPTION AND FORECAST HEAT DEMAND FOR RESIDENTIAL SPACE HEATING}

\section{Summary}

Heating degree-days (HDD) are used to evaluate and compare heat consumption in buildings at various climate. HDD calculation is based on climate parameters and base temperature. The base temperature is equal to balance temperature of a building when heat gains compensate heat loss. Implementation of energy-efficient buildings means lesser loss and higher role of heat gains. The problem is to which level of heat consumption in various climates HDD are a reliable tool to compare heat consumption and to forecast heat demand.

Heat consumption per one HDD, if base temperature is set right, does not depend on the HDD number of the given period. The conclusion is drawn that the number of HDD based on $18{ }^{\circ} \mathrm{C}$ or similar is not applicable to energy-effective buildings. Periods of high outdoor temperature when energy-effective buildings do not need heating are included into the number of HDD18.

After heat consumption comparison in various Lithuania's towns, the base temperature is considered to be $8{ }^{\circ} \mathrm{C}$ if heat consumption is $40 \mathrm{kWh} / \mathrm{m}^{2} \mathrm{a}$, and $10{ }^{\circ} \mathrm{C}$ at $75 \mathrm{kWh} / \mathrm{m}^{2} \mathrm{a}$, respectively. There are no essential differences between construction traditions and living habits of the Baltic States, so these base temperatures may be applicable in all East Baltic Coast States.

Key words: heating degree-days, energy-effective buildings, base temperature 
Эгидиюс Юодис

ПРЕДЕЛЫ ПРИМЕНИМОСТИ ГРАДУСО-ДНЕЙ ДЛЯ СРАВНЕНИЯ И ПРОГНОЗА ТЕПЛОПОТРЕБЛЕНИЯ НА ОТОПЛЕНИЕ ЖИЛЫХ ЗДАНИЙ

Резюме

Для оценки и сравнения теплопотребления зданиями в местностях с разным климатом используются градусо-дни отопления. Расчет градусо-дней основан на климатических характеристиках местности и базовой температуре. Базовая температура по определению равна балансной температуре здания при которой тепловыделения компенсируют теплопотери зданием.

При переходе к строительству энерго-эффективных зданий теплопотери снижаются, возрастает роль тепловыделений. Возникает вопрос до какого уровня теплопотерь градусо-дни являются достаточно надежным инструментом для сравнения и оценки теплопотерь в разном климате и для прогноза теплопотребления. Теплопотребление, отнесенное к одному градусо-дню, при правильном подборе базовой температуры не зависит от числа градусо-дней отопления данного периода. На основе этого исходя из сравнения данных коммерческого расчета теплоснабжающих организаций Литвы за тепло на отопление многоквартирных зданий и теплопотребления, отнесенного на один градус день, делается вывод, что градусодни на основе базовой температуры $18{ }^{\circ} \mathrm{C}$ или близкой к ней не должны применяться для энерго-эффективных зданий ибо включает в себя периоды, когда энерго-эффективные здания не нуждаются в отоплении.

Базовая температура для зданий, теплопотребление которых составляет 40 кВтч/м² год, определена равной $8{ }^{\circ} \mathrm{C}$, а при теплопотреблении 75 кВтч/м² год - $10^{\circ} \mathrm{C}$. Нет существенных различий между строительными традициями, образом жизни и оснащенностью бытовыми приборами жителей Литвы и сопредельных стран, поэтому можно утверждать, что эти базовые температуры применимы во всех странах восточного Балтийского побережья.

Ключевые слова: градусо-дни отопления, энерго-эффективные здания, базовая температура 